\title{
Short communication: Flooring preferences of dairy cows at calving
}

\author{
M. Campler, ${ }^{\star} †$ L. Munksgaard, $†$ M. B. Jensen, $†$ D. M. Weary, ${ }^{*}$ and M. A. G. von Keyserlingk ${ }^{* 1}$ \\ *Animal Welfare Program, Faculty of Land and Food Systems, University of British Columbia, 2357 Mall, Vancouver, British Columbia, \\ V6T 1Z4, Canada \\ †Department of Animal Science, Aarhus University, PO Box 50, 8830 Tjele, Denmark
}

\begin{abstract}
The present study investigated the flooring preference during the $30 \mathrm{~h}$ before parturition in Holstein dairy cows housed individually in a maternity pen. Seventeen multiparous cows were moved, on average, $2 \mathrm{~d}$ before expected calving date into an individual maternity pen with 3 different flooring surfaces: $10 \mathrm{~cm}$ of sand, pebble-top rubber mats, or concrete flooring, each covered with $15 \mathrm{~cm}$ of straw. Calving location, lying time, and total time and number of lying bouts on each of the floor types were recorded during 2 periods: precalving (24 to $29 \mathrm{~h}$ before calving) and at calving ( 0 to $5 \mathrm{~h}$ before calving). Ten cows calved on sand, 6 on concrete, and 1 on the rubber mat. Lying bouts increased during the hours closest to calving, regardless of flooring. The number of lying bouts did not differ between flooring types precalving but cows had more lying bouts on sand and concrete compared with rubber at calving. Cows spent more time lying down on sand and concrete compared with rubber precalving, but lying times did not differ between treatments at calving. Cows that calved on sand spent more time lying on sand at calving compared with the other 2 flooring types. Cows that calved on concrete did not show a flooring preference at calving. These results indicate that rubber mats are the least preferred by dairy cows in the maternity pens, even when covered with a deep layer of straw.
\end{abstract}

Key words: cow comfort, preference test, lying time, parturition

\section{Short Communication}

Compared with free-ranging ungulates, indoorhoused dairy cows have few options as to where they give birth. One common practice is to separate cows from the herd upon signs of parturition to an individual maternity pen (Proudfoot et al., 2013). Common flooring surfaces in maternity pens include sand, grooved

Received July 12, 2013.

Accepted October 11, 2013.

${ }^{1}$ Corresponding author: nina@mail.ubc.ca concrete, and rubber mats or mattresses, and a thick layer of straw or other organic material is often added to the flooring surface (Cook and Nordlund, 2004). The majority of research on cow comfort has focused on the lactating cow (von Keyserlingk et al., 2009) but little work has focused on the time around parturition. Previous studies have shown that lactating cows prefer to lie down on thick (Tucker et al., 2009), soft (Tucker and Weary, 2004), and dry (Reich et al., 2010) bedding materials and that sand or straw beddings are preferred over rubber mats or mattresses (Calamari et al., 2009). Cows also show longer lying times and a higher number of transitions between lying and standing on mattresses (Haley et al., 2001) and rubber mats (Rushen et al., 2007) compared with concrete flooring. The flooring in the maternity pens may be especially important at the time of calving, as cows frequently change position in the hours leading up to parturition. In the $2 \mathrm{~d}$ before calving, cows double the number of transitions between lying and standing to approximately 22 standing bouts in the $24 \mathrm{~h}$ before calving (Huzzey et al., 2005). The majority of this increase occurs in the $6 \mathrm{~h}$ before calving (Miedema et al., 2011; Jensen, 2012). Changing position from lying to standing (or the reverse) may be hazardous or unpleasant on a hard and slippery surface (Rushen et al., 2007) especially at the time around calving. The objective of this study was to investigate lying behavior and flooring preferences of dairy cows in the hours leading up to calving.

Seventeen multiparous cows (parity $=2.8 \pm 0.4$, mean $\pm \mathrm{SE}$ ) were used in this study that was conducted from late June to mid October 2012 at the University of British Columbia Dairy Education and Research Centre (Agassiz, BC, Canada). Before testing, all cows were housed in a pen with 12 freestalls with a mattress base covered with approximately $5 \mathrm{~cm}$ of washed river sand. Cows entered and exited the pen depending upon their expected calving date and were monitored daily by experienced herdsmen for injuries or indications of lameness. Cows that were classified as injured or lame were not used in the study. The indoor temperature during the study was registered by sensors (HOBO Pro v2 Temp/Ext Temp logger; Measurement Systems Ltd., UK), with an average $( \pm \mathrm{SD})$ temperature of 18.1 
$\pm 5.6^{\circ} \mathrm{C}$, a minimum of $9.2^{\circ} \mathrm{C}$, and a maximum of $34.1^{\circ} \mathrm{C}$. All methods used to collect data were approved by the University of British Columbia's Animal Care Committee, which follows the standards outlined by the Canadian Council on Animal Care (CCAC, 2009).

Two days before the expected calving date, or upon physical signs of approaching calving (e.g., enlarged and tense udder or loose pelvic ligaments), cows were moved from the close-up pen into a test pen $(8.1 \times 3.7$ $\mathrm{m})$. The test pen was divided into 3 separate equally sized areas (each $2.7 \times 3.7 \mathrm{~m}$ ) with different flooring: (1) grooved concrete, (2) an 18-mm-thick pebble top rubber mat (North West Rubber Ltd., Abbotsford, BC, Canada), or (3) $10 \mathrm{~cm}$ of washed river sand. All 3 treatments were covered with a $15-\mathrm{cm}$ layer of straw. Wooden boards $(3.7 \mathrm{~m} \times 5.1 \mathrm{~cm} \times 10.2 \mathrm{~cm})$ were secured to the floor separating the 3 flooring surfaces and associated bedding, preventing cows from lying across flooring types. Cows had free access to all flooring types within the test pen until they calved. The test pen was cleaned twice per day and straw was replenished and evenly spread out when the cow was fed. Flooring materials were repositioned in between every third cow to eliminate any confounding effect of location.

One long side of the test pen was gated to provide a partial view of cows housed in nearby pens. Water was provided ad libitum from a portable self-filling bowl and feed was delivered twice daily in a portable feed trough at approximately 0700 and $1600 \mathrm{~h}$. To prevent feed and water to act as a confounding factor, both were repositioned separately between treatments at each feed delivery.

Cow location and lying times were recorded using a surveillance camera (CCTV, WV-BP334; Panasonic Corp., Osaka, Japan), installed on one short side $3 \mathrm{~m}$ over the test pen, that was connected to a DVR unit (GeoVision Inc., Taipei, Taiwan). Red floodlight bulbs (NOMA, 100W; Trileaf Distribution, Toronto, ON, Canada) facilitated video recordings at night.

Calving location, lying location as well as lying time, total time (standing and lying time), and number of lying bouts on each floor type were measured. Previous work (Proudfoot et al., 2009; Miedema et al., 2011; Jensen, 2012) has shown that behavioral changes associated with calving peak within $6 \mathrm{~h}$ of parturition. We split our data into two 6-h periods: precalving (24 to $29 \mathrm{~h}$ before calving) and calving ( 0 to $5 \mathrm{~h}$ before calving). Four out of the 17 cows calved within $30 \mathrm{~h}$ of being moved into the maternity pen and thus were not included in the precalving analysis. A single trained observer recorded all behaviors from continuous video recordings (GeoVision 1480 digital recorder; USA Vision Systems Inc., Irvine, CA).
To test if calving location varied with flooring (i.e., sand, rubber mats, or concrete) we used a chi-squared goodness-of-fit test. This same test was used to test if calving location varied with location within the pen, regardless of flooring (i.e., left, right, or mid position). To test if lying behavior also varied with treatment and period relative to calving (i.e., precalving or calving), differences in lying time and number of lying bouts were analyzed by a Friedman 2-way ANOVA (Siegel and Castellan, 1988), with results presented as medians (and 25th and 75th quartiles). Where treatment differences were found, a Wilcoxon matched-pairs signed-rank test (Siegel and Castellan, 1988) was used for a post-hoc pairwise analysis. Finally, to test if a cow's preference for the different flooring types before calving varied in relation to the flooring they chose to calve upon, total time (lying + standing) and lying time spent on each flooring type were compared for cows calving on each of the flooring types using a Friedman 2-way ANOVA (Siegel and Castellan, 1988). Significance was declared at $P<0.05$.

Ten cows calved on sand versus just 1 cow on the rubber mats $\left(\mathrm{df}=1, \chi^{2}=5.66 ; P<0.05\right) ; 6$ cows calved on concrete, a value not statistically different from either the sand or rubber. We found no effect of location (left, right, or mid position); 8 cows calved in the middle, 5 calved on the left side, and 4 calved on the right side of the pen. This preference for sand is in contrast with results from Manninen et al. (2002), who found that lactating cows preferred freestalls with concrete and a thick layer of straw and rubber mats with a thin layer of straw over sand and Norring et al. (2010) who observed no preference for freestalls with sand compared with freestalls with rubber mats or concrete. To some degree, it is surprising that our cows showed a preference for sand flooring, given that all 3 options were covered with $15 \mathrm{~cm}$ of straw. Our decision to bed each of the surfaces with straw was in response to previous work showing the importance of dry bedding (Fregonesi et al., 2007). The straw layer itself may have been thick and soft enough to accommodate a high degree of lying comfort across all floorings at the time of calving. Jensen et al. (1988) observed a weak overall preference for mattresses covered with a thin layer of straw compared with concrete covered with a thick layer of straw, but only when the straw was old or straw levels were low in the concrete stalls. Drissler et al. (2005) reported that lying time decreased with decreasing sand depth. Although straw in the current study was replenished and leveled out twice per day, its depth at the time of calving may have influenced the cows' decisions and should be considered in future studies. It should be noted that all cows had previous 
experience with sand bedding, as well as with both concrete and rubber as standing surfaces. The cows' low preference for rubber flooring in the current study may also have been due to unfamiliarity with this surface in the lying area. Previous experience has been shown to influence the results of a preference test (Norring et al., 2008). However, cows were not familiar with lying on concrete, so familiarity cannot fully explain these results. The low sample size may also have affected the outcome of this study.

The number of lying bouts did not differ between flooring types in the precalving period but cows lay down more often on sand compared with the rubber mats during the calving period (Table 1). No effect of location on the number of lying bouts was observed in either period. Our results agree with Huzzey et al. (2005) and Jensen (2012), who also found an increased number of lying bouts close to parturition. The higher number of transitions on sand may have been due to better traction on this surface compared with rubber mats (Cook and Nordlund, 2009) or concrete (Telezhenko and Bergsten, 2005).

Cows spent more time lying on sand and concrete compared with rubber mats precalving, but this difference was no longer evident during the calving period. During the calving period, cows tended to spend the majority of time lying on sand. This result may have been affected by an increase in restlessness that occurs close to parturition. We found no effect of location on lying time in either period.

Cows that chose to calve on sand spent more time overall on sand compared with rubber [Wilcoxon test statistic $(\mathbf{W})=27.5$, Wilcoxon standard normal value $(\mathbf{z})=-2.395 ; P=0.002 ; \mathrm{n}=10$, adjusted for ties; Figure 1A] or concrete $(\mathrm{W}=27.5, \mathrm{z}=-2.4973 ; P=$ $0.012 ; \mathrm{n}=10$, adjusted for ties; Figure 1B) and also had longer lying times on sand compared with rubber $(\mathrm{W}=27.5, \mathrm{z}=-2.803 ; P=0.005 ; \mathrm{n}=10$, adjusted for ties) and concrete $(\mathrm{W}=27.5, \mathrm{z}=-2.497 ; P=0.012 ; \mathrm{n}$ $=10$, adjusted for ties) in the calving period. No difference in time spent overall $\left(\chi^{2}=2.33, \mathrm{df}=2 ; P>0.05\right.$; $\mathrm{n}=6$, adjusted for ties $)$ or lying $\left(\chi^{2}=1.33, \mathrm{df}=2 ; P>\right.$ $0.05 ; \mathrm{n}=6$, adjusted for ties) on the different flooring materials was observed for cows that chose to calve on concrete. Only 1 cow chose to calve on rubber, so this treatment was not included in this analysis. Thickness and compressibility of the bedding has been shown to affect lying behavior (Tucker and Weary, 2004; Tucker et al., 2009). We suggest that future studies investigate flooring preferences in combination with variable bedding thickness in the maternity pen to determine how these factors may interact.

In conclusion, cows preferred sand to rubber mats during calving in a free-choice setting. Lying times and lying bouts occurred mainly on sand and concrete flooring during the study, suggesting that cows avoid rubber flooring in the maternity pen.

\section{ACKNOWLEDGMENTS}

The authors are grateful to the farm staff and students who helped throughout the course of this experiment. M. Campler gratefully acknowledges the University of British Columbia (UBC, Vancouver, BC, Canada) Graduate Student International Research Mobility Award, the Danish Cattle Federation (Aarhus, Denmark); the Danish Ministry of Food, Agriculture and Fisheries (Copenhagen, Denmark); Aarhus University Research Fund (Tjele, Denmark); and the Danish Agricultural Research Fund (Hudefonden). The UBC Animal Welfare Program is funded through the Natural Sciences and Engineering Research Council of Canada (NSERC, Ottawa, ON, Canada) Industrial Research Chair program, with industry contributions from the Dairy Farmers of Canada (Ottawa, ON, Canada), Westgen Endowment Fund (Milner, BC, Canada),

Table 1. Time spent lying ( $\mathrm{min} / 6 \mathrm{~h}$ ) and the number of lying bouts (no. $6 \mathrm{~h}$ ) on each of the 3 flooring surfaces in the precalving period ( 24 to $29 \mathrm{~h}$ before calving; $\mathrm{n}=13$ ) and during the 6 - $\mathrm{h}$ period before calving $(0$ to 5 $\mathrm{h} ; \mathrm{n}=17)^{1,2}$

\begin{tabular}{|c|c|c|c|c|c|c|}
\hline \multirow[b]{2}{*}{ Variable } & \multicolumn{3}{|c|}{ Flooring surface } & \multirow[b]{2}{*}{$x^{2}$} & \multirow[b]{2}{*}{ df } & \multirow[b]{2}{*}{$P$-value } \\
\hline & Sand & Rubber & Concrete & & & \\
\hline \multicolumn{7}{|l|}{24 to $29 \mathrm{~h}$ before calving $(\mathrm{n}=13)$} \\
\hline Lying time (min) & $91^{\mathrm{a}}(0-156)$ & $0^{\mathrm{b}}(0-0)$ & $73^{\mathrm{a}}(0-118)$ & 8.00 & 2 & 0.05 \\
\hline Lying bouts (no.) & $2(1-3)$ & $0(0-0)$ & $1(0-2)$ & 4.19 & 2 & NS \\
\hline \multicolumn{7}{|l|}{0 to $5 \mathrm{~h}$ before calving $(\mathrm{n}=17)$} \\
\hline Lying time (min) & $157(0-243)$ & $49(0-172)$ & $31(0-73)$ & 4.80 & 2 & 0.09 \\
\hline Lying bouts (no.) & $4^{\mathrm{a}}(2-6)$ & $0^{\mathrm{b}}(0-1)$ & $1^{\mathrm{ab}}(0-4)$ & 7.53 & 2 & $<0.001$ \\
\hline
\end{tabular}

${ }^{\mathrm{a}, \mathrm{b}}$ Medians within a row with different superscript letters differ $(P<0.05)$ according to the Wilcoxon matchedpairs rank test.

${ }^{1} \chi^{2}$, df, and $P$-value represent Friedman statistics.

${ }^{2}$ Lying times and lying bouts are presented as the median (25th quartile-75th quartile). 


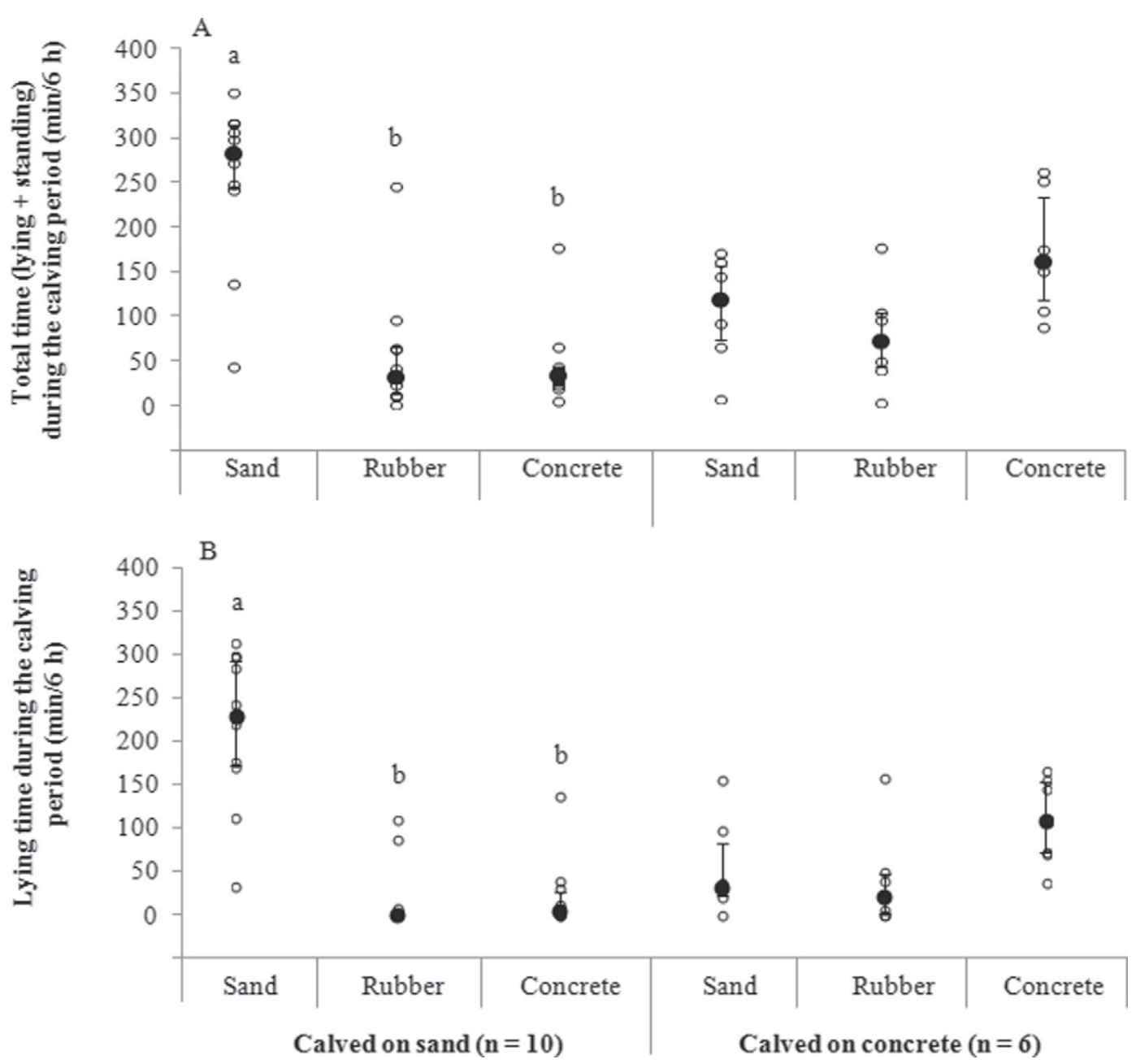

Figure 1. (A) Total lying and standing time $(\mathrm{min} / 6 \mathrm{~h})$ and $(\mathrm{B})$ total lying time $(\mathrm{min} / 6 \mathrm{~h})$ on each of the 3 flooring surfaces during the calving period ( 0 to $5 \mathrm{~h}$ before calving) for cows that calved on sand $(\mathrm{n}=10)$ and concrete $(\mathrm{n}=6)$, respectively. Filled circles represent median $(25$ th and 75th quartiles are indicated) and open circles represent individual cows. Medians with different letters are significantly different $(P<0.05)$ according to the Wilcoxon matched-pairs rank test.

Zoetis (Kirkland, QC, Canada), BC Cattle Industry Development Fund (Kamloops, BC, Canada), the BC Dairy Association (Burnaby, BC, Canada), and Alberta Milk (Edmonton, AB, Canada).

\section{REFERENCES}

Calamari, L., F. Calegari, and L. Stefanini. 2009. Effect of different free stall surfaces on behavioural, productive and metabolic parameters in dairy cows. Appl. Anim. Behav. Sci. 120:9-17.

CCAC (Canadian Council on Animal Care). 2009. CCAC Guidelines On: The Care and Use of Farm Animals in Research, Teaching and Testing. CCAC, Ottawa, ON, Canada.

Cook, N. B., and K. V. Nordlund. 2004. Behavioral needs of the transition cow and considerations for special needs facility design. Vet. Clin. North Am. Food Anim. Pract. 20:495-520.

Cook, N. B., and K. V. Nordlund. 2009. The influence of the environment on dairy cow behavior, claw health and herd lameness dynamics. Vet. J. 179:360-369.

Drissler, M., M. Gaworski, C. B. Tucker, and D. M. Weary. 2005. Freestall maintenance: Effects on lying behavior of dairy cattle. J. Dairy Sci. 88:2381-2387.
Fregonesi, J. A., D. M. Veira, M. A. G. von Keyserlingk, and D. M. Weary. 2007. Effects of bedding quality on lying behavior of dairy cows. J. Dairy Sci. 90:5468-5472.

Haley, D. B., A. M. de Passillé, and J. Rushen. 2001. Assessing cow comfort: Effects of two floor types and two tie stall designs on the behaviour of lactating dairy cows. Appl. Anim. Behav. Sci. 71:105-117.

Huzzey, J. M., M. A. G. von Keyserlingk, and D. M. Weary. 2005. Changes in feeding, drinking, and standing behavior of dairy cows during the transition period. J. Dairy Sci. 88:2454-2461.

Jensen, M. B. 2012. Behavior around the time of calving in dairy cows. Appl. Anim. Behav. Sci. 139:195-202.

Jensen, P., B. Recen, and I. Ekesbo. 1988. Preference of loose housed dairy cows for two different cubicle floor coverings. Swed. J. Agric. Res. 18:141-146.

Manninen, E., A. M. de Passillé, J. Rushen, M. Norring, and H. Saloniemi. 2002. Preferences of dairy cows kept in unheated buildings for different kind of cubicle flooring. Appl. Anim. Behav. Sci. $75: 281-292$.

Miedema, H. M., M. S. Cockram, C. M. Dwyer, and A. I. Macrae. 2011. Changes in the behaviour of dairy cows during the $24 \mathrm{~h}$ before normal calving compared with behaviour during late pregnancy. Appl. Anim. Behav. Sci. 131:8-14. 
Norring, M., E. Manninen, A. M. de Passillé, J. Rushen, L. Munksgaard, and H. Saloniemi. 2008. Effects of sand and straw bedding on the lying behavior, cleanliness, and hoof and hock injuries of dairy cows. J. Dairy Sci. 91:570-576.

Norring, M., E. Manninen, A. M. de Passillé, J. Rushen, and H. Saloniemi. 2010. Preferences of dairy cows for three stall surface materials with small amounts of bedding. J. Dairy Sci. 93:70-74.

Proudfoot, K. L., J. M. Huzzey, and M. A. von Keyserlingk. 2009. The effect of dystocia on the dry matter intake and behavior of Holstein cows. J. Dairy Sci. 92:4937-4944.

Proudfoot, K. L., M. B. Jensen, P. M. Heegaard, and M. A. G. von Keyserlingk. 2013. Effect of moving dairy cows at different stages of labor on behavior during parturition. J. Dairy Sci. 96:16381646.

Reich, L. J., D. M. Weary, D. M. Veira, and M. A. G. von Keyserlingk. 2010. Effects of sawdust bedding dry matter on lying behavior of dairy cows: A dose-dependent response. J. Dairy Sci. $93: 1561-1565$
Rushen, J., D. Haley, and A. M. de Passillé. 2007. Effect of softer flooring in tie stalls on resting behavior and leg injuries of lactating cows. J. Dairy Sci. 90:3647-3651.

Siegel, S., and N. J. Castellan Jr. 1988. Nonparametric Statistics for the Behavioral Sciences. 2nd ed. McGraw-Hill, New York, NY.

Telezhenko, E., and C. Bergsten. 2005. Influence of floor type on the locomotion of dairy cows. Appl. Anim. Behav. Sci. 93:183-197.

Tucker, C. B., and D. M. Weary. 2004. Bedding on geotextile mattresses: How much is needed to improve cow comfort? J. Dairy Sci. $87: 2889-2895$

Tucker, C. B., D. M. Weary, M. A. G. von Keyserlingk, and K. A. Beauchemin. 2009. Cow comfort in tie-stalls: Increased depth of shavings or straw bedding increases lying time. J. Dairy Sci. 92:2684-2690.

von Keyserlingk, M. A. G., J. Rushen, A. M. de Passillé, and D. M. Weary. 2009. Invited review: The welfare of dairy cattle-Key concepts and the role of science. J. Dairy Sci. 92:4101-4111. 